\title{
Introduction: Deviance and Defiance
}

\section{Joel Faflak \& Michael Eberle-Sinatra}

To cite this article: Joel Faflak \& Michael Eberle\#Sinatra (2006) Introduction: Deviance and Defiance, European Romantic Review, 17:2, 133-138, DOI: $10.1080 / 10509580600687442$

To link to this article: http://dx.doi.org/10.1080/10509580600687442

曲 Published online: 19 Aug 2006.

Submit your article to this journal 준

III Article views: 60

Q View related articles $\sqsubset$ 


\section{Introduction: Deviance and Defiance Joel Faflak \& Michael Eberle-Sinatra}

The thirteenth annual meeting of the North American Society for the Study of Romanticism took place August 13-16, 2005 in Montreal, Canada, sponsored by Université de Montréal. The conference was held in conjunction with the seventh biennial meeting of the International Gothic Association (August 11-14) and was the first major collaborative effort between NASSR and IGA. The theme for both conferences was "Deviance and Defiance," to underscore the fact that in recent years the interrelation of Gothic and Romantic studies has emerged as a central topic of scholarly study. This interest reflects both fields' reclamation of the often transgressive texts and authors who articulate the epoch-making intersection of Gothic and Romantic literatures in the later eighteenth and early nineteenth centuries. "Deviance and Defiance" was thus the first major international and interdisciplinary meeting to assess how the convergence of the Gothic and the Romantic produced historical forces whose cultural resonance persists to the present and, by the evidence of the presentations at both conferences, survives in ways that make our critical practice more than just a theoretical exercise.

Joel Faflak is Assistant Professor in the Department of English at the University of Western Ontario. He has edited Sanity, Madness, Transformation: The Psyche of Romanticism (2005), a special issue of European Romantic Review on Romanticism and History (2003), and co-edited Nervous Reactions: Victorian Recollections of Romanticism (2004) and Cultural Subjects: A Popular Culture Reader (2005). He has published numerous articles on the relationship between Romantic and post-Romantic literature and culture and psychoanalysis, and has forthcoming an edition of Thomas De Quincey's Confessions of an English Opium-Eater and a book-length study entitled Romantic Psychoanalysis and the Burden of the Mystery. He can be contacted at UC 60, Department of English, University of Western Ontario, London, Ontario N6A 3K7, Canada. Michael Eberle-Sinatra is Assistant Professor of Nineteenth-Century British Literature. His publications include a dozen articles on Romantic authors in such journals as European Romantic Review, Byron Journal, Keats-Shelley Journal, and Keats-Shelley Review. Routledge published his monograph, Leigh Hunt and the London Literary Scene, in 2005. He is the editor of Mary Shelley's Fictions: From Frankenstein to Falkner (Macmillan, 2000), the general editor, with Thomas Crochunis, of the forthcoming Broadview Anthology of British Women Playwrights, 1777-1843 (Broadview Press, 2007), and one of the general editors of the six-volume edition of The Selected Writings of Leigh Hunt (Pickering \& Chatto, 2003). He has recently been contracted by Longman to prepare a critical edition of Matthew Lewis's Gothic novel, The Monk, to be published in 2007. He is also founding editor of the electronic peer-reviewed journal, Romanticism on the Net. He can be contacted at Departement d'études anglaises, Universite de Montreal CP 6128, Station Centre-ville, Montreal, Quebec H3C3J7, Canada. 
The joint theme capitalized on two salient phenomena in recent scholarship: the study of the Gothic's influence on the cultural imaginary has grown exponentially, and Romantic studies has enlarged its critical and disciplinary boundaries by re-internalizing the gothic as one of its most significant origins. Both fields have been engaged in reassessing how the Gothic and Romanticism establish and challenge norms that exist as remains in our own day. Gothic and Romantic discourses have profoundly shaped historical, political, and cultural issues, such as the emergence of resistance groups and suffrage movements in the eighteenth, nineteenth, and twentieth centuries; exploration, colonialism, postcolonialism, and the rise of the imperialist imagination and its frequently monstrous aftermaths; the romance of scientific revolutions and their often Gothic progeny; the War on Terror. The Gothic and the Romantic both defy and reinforce norms, re-trench common wisdom while defying its codes of conduct. They write these issues large on the literary, cultural, and political stages, in the classroom and in society. Romanticism and the Gothic continue to haunt our political unconscious and to mold historical and cultural consciousness in ways that we are just beginning to understand, and that will affect how we imagine, create, and teach cultural texts and artefacts long into the twenty-first century.

The topic thus engaged deviance and defiance from multiple perspectives, and invited a profound attention to historical context, while encouraging innovative comparative analyses that reorder our sense of history and how that history informs the critical practice of our everyday lives. For NASSR participants in particular, the Gothic comprised a semi-autonomous field for historical and cultural inquiry within Romantic Studies. By now, one could argue, study of the Gothic in the Romantic period is an institution unto itself, whereas before it had been the criticism's marginal or, worse, occult concern. Yet it is precisely this slippage between center and periphery that the conference sought to interrogate in order to ascertain how and why subjects get located in the (Romantic) public sphere the ways they do. In this way the idea of the Gothic functioned most profoundly for participants as a metonymy for all that the period and its criticisms did not and could not leave behind, for its penchant for shifting paradigms and smashing shibboleths while remaining deeply ambivalent about history's advance. We need look no further than the paradigmatic example of Wordsworth's indictment of sickly German tragedies or his attempts to minimize the ghastly horrors of Coleridge's frequently supernatural achievement to know that the Gothic was, at least by the time Wordsworth wrote his Preface, a force to be reckoned with, one that affected how individuals thought and felt. As Michael Gamer, the joint NASSR/IGA plenary speaker, reminds us in a recent article on pornography and the Gothic in PMLA, the Gothic was enlisted in the name of making pornography an indictable category because it offered a way of designating in human nature and in an increasingly unwieldly public and imperial sphere transgressive thoughts and acts that, by virtue of being marked transgressive, required legislation and containment. That is, the centering impetus of the Romantic public sphere, its desire to conserve itself-politically, culturally, economically, sexually, nationally, racially-depended on the naming and maintenance of its margins as differences that kept its identity intact. NASSR 2005 addressed itself to this unstable hegemony, to a literature and culture whose deviances 
and defiances become spectres of the period's productive desire for and troubling addiction to revolution and radicalism, progress and change.

From the conference's heterogeneous field of inquiry we have chosen what we hope is a varied yet exemplary sampling of NASSR 2005's excellent and timely presentations. We include, for instance, one of the four stellar plenary presentations, Tim Fulford's "Romantic Indians and their Inventors." Fulford looks at the figure of the British born and educated Captain John Norton, who also happened to be Teyoninhokarawen, a Mohawk chief who lead British and Indian soldiers against the US in the war of 1812. Divided between two solitudes, one North American, the other European, Norton reminds us of how culture trains its subjects according to its own receptivity toward them, in this case toward a man who they presumed had the "body and mind of a 'savage' - a man of nature, untouched, for good and ill, by civilization." Teyoninhokarawen needed to be "native" in ways of which his own community, with its own cultural constructions, would have been suspicious; yet his "adopted" community was equally suspicious that, as a proper British gentleman, he was not "savage enough." Such a figure of cultural hybridity does and does not conform to British self-assessments, a transatlantic trickster whose mobile identities confronted the Empire with its own foreignness, its own deviation from itself, one who consequently played into stereotypes and defied their prejudices. A different negotiation across the pond informs Cole Heinowitz's “'Thy World, Columbus, Shall Be Free’: British Romantic Deviance and Latin American Revolution.” Heinowitz's essay traces a cultural kinship between British liberal dissent (in Barbauld's poetry) and Latin American patriotism (in Simón Bólivar's political writing), the former displacing the afflatus of Romantic vision from an Alpine to an Andean locus that reproduces consciousness as political revolution and reminds a hegemonic British Romanticism of its complicity with its own suppressed resistances. For Heinowitz, the moral economies of economic and political liberalism, and their presumption of benevolence, circulate between Britain and Spanish America through a mobile cultural commerce that, far from shoring up the Empire's selfhood, writes back to the Empire a rather unexpected account of its own benevolent ideals. Thus Fulford's and Heinowitz's essays contest what the "North American" in NASSR might possibly mean, and demonstrate that we are only beginning to bring some insight to bear on such blindnesses.

Both essays also point to a concern with ethical practice in recent Romantic criticism (and thus with the spectres of ethical critical practice), following upon a turn to an analysis of Romanticism's political unconscious (and this after the ongoing re-turn to history). Such a concern is ostensible, if not overt, in many of NASSR 2005's papers. Arnold Markley and Laura Mandell read this ethics through two countervalent portraits of the Romantic public sphere's deviating practices. Markley's focus is gambling and duelling in the 1790s novel of reform. Here upper-class gaming and swordsmanship are re-signified as bad behaviours, deviating practices in which the allure of chivalry and the ability to transcend the whims of fortune become tradition's desperate last stand against the inevitability of historical and political change. At work in the genre's re-formation is the spirit of a middle-class industriousness that could not broach such resistances to transformation, especially as middle-class concern about 
addictive and dangerous practices rose commensurate with its anxiety toward the working classes. For Mandell the site of ambivalent transaction is letters (between Horace Walpole and Mme. du Deffand and between Mary Hays and William Godwin). Here the anxieties negotiating between subjects are aggression and hatred. Such written, transcribed, edited and re-edited exchanges comprise for Mandell a scene of narcissistic psychoanalysis that demystifies a later classical psychoanalysis' production of normal and normative selves. In the case of Hays and Godwin the interchange reveals a Romantic identity absent to itself because of gender tensions it misses; in the case of Walpole and Deffand, the scene folds in upon itself to reveal an identity lost, if not absent altogether. Both options offer a kind of primal scene of conversation-the driving force sustaining Godwinian political justice-wherein the merger of the private and public points to this merger's less-than-transformative capacities. A similar merger appears in Emily Rohrbach's essay on Barbauld's Eighteen Hundred and Eleven and the way the poem addresses a new kind of historicized identity and transatlantic issues. Exploring the blurriness between philosophies of historical progress and the culture of dissent, Rohrbach analyzes Barbauld's deviancy from contemporary settings and national perspectives, while reasserting that the poem "presents itself as a medium for British nationalism."

It seems an uncanny anomaly that, in a conference devoted to the theme of deviance and defiance, there were such a large number of papers devoted to some of the period's more "conservative" figures such as William Wordsworth and Jane Austen, just as Godwin recurs as one of Romanticism's more distinctly ambivalent writers. Yet one of NASSR 2005's most productive and, indeed transgressive, aspects was to look for critical deviations in the least obviously, as well the more characteristically, defiant places. Three papers we have included here, for instance, remind us how we can still be startled by Wordsworthian errancy (to borrow David Collings's phrase). For Peter J. Manning, the case for Wordsworth is a case for revisiting the historical and political valences of his late poetry, still much overlooked in the criticism. Relocating Persepolis as a figure of timeless utterance to one of topical iteration in Yarrow Revisited, Manning explores a later, supposedly disinterested Wordsworth who seems to be well aware of Britian's "global entanglements." Persia, signalling both the Empire's cultural survival and its hegemony over the past, also signals in Wordsworth's texts ambivalent feelings about both and thus about foreign aspects of and intrusions within its own apparently homogeneous space. Cara Norris reads an earlier Wordsworth rather less ambivalent about politics, particularly those of the 1790s in The Borderers, which speaks to an absent center of justice (the 1794 suspension of habeus corpus) propelling a series of narrative deviations from that center, narratives that simulate rather than effect justice as simulation. In the play we thus find Wordsworth casting futurity's shadows upon his own present in the form of a political system that trades in spectacular narratives and narrative speculation in the name of protecting a civil society. Most frightening in this process is the simulation of an "independent intellect" for the sake of then manipulating that independence's ethical autonomy. For Nancy Yousef, such an autonomy raises ethical concerns in Wordsworth's "The Discharged Soldier." Wordsworth's text demonstrates the epistemological tensions inherent in an eighteenth-century concern 
with moral sentiment that Wordsworth inherits. Sympathy galvanizes subjects into a community of feeling, but does not necessarily make this feeling commensurate with justice. Put another way, the self-love that is supposed to be sympathy's prelude to moral action does not always equate with a concern for the greater good, a sympathetic disappointment whose paradox Wordsworth's text rather too keenly feels itself.

The case for Austenian defiance is equally telling. Terry F. Robinson's essay, winner of this year's prize for Best Graduate Student Essay at the NASSR conference, explores how Austen's Northanger Abbey, through its apparently conservative turn to the past, is in fact a return back to the future of a Romantic historiography that deviates from the time's overtly Protestant ethic about this historiography's work. The writing of individual fancy in Austen's 'romantic' heroine Catherine, informed by a Catholicized historiography in which relics of the past maintain a potent signifying fascination, frees subjects from the ideological tyranny of a presentist, masculinist, Protestant concern with the skeletal anatomy of facts and the truth, exemplified by Henry Tilney's world view. In fact, such a notion of "fancy's history," to borrow Julie Carlson's phrase, at once predicates history upon the abyss and allows subjects closer access to history's real; it thus also offers a degree of future autonomy that submits the Enlightenment's rationalist promise to a psychoanalysis of its common sense assumptions. Robinson's paper thus also offers a critique of our present critical historiographies and their sometimes profound attachment to historical reality. As in Godwin's ambivalent historiography, so crucial to Austen's championing of the novel, to her re-visioning of British history, and to Robinson's argument about the Romanticism's attachment to history's romance, Robinson reminds us how history is written by the movement of its own desire. Joanna Aroutian then takes up this desire as family romance in Mansfield Park. Aroutian reads the novel as the tension between an adherence to the inertness of family alliances and kinships and a dangerously mobile sexuality-both, because of their excessive deployment, threatening to unravel the ties that bind. Such a tension is made dialectically productive and thus socially progressive in the figure of Fanny Price, who manages to negotiate the powerful matrices of sexuality within the family system without making one succumb to the other. Such a gesture in some ways signals the novel's social compromise. For Aroutian it suggests instead a subtly deviant Austen whose apparent sexual and gender conservatism can be powerfully forward-thinking.

Such progress turns not-so-subtly traumatic in Daniela Garofalo's essay on Caleb Williams, which owes much to the recent focus on Godwin's historiography and its traumatic ambivalence toward both the real and the possibility of political justice (as in the recent work of Tilottama Rajan). Garofalo reads the narrative of the law, as explored in Norris's account of The Borderers, as Godwin's cynical simulation of its fictive authority. The novel's most modern turn, she argues, is not to unmask this authority's absolute power, but rather the effective economizing of its own failure, figured in Falkland's fallible patriarchy: “in Godwin's world what stimulates a lasting belief in the coherence of the law is not the tyrant [Tyrell] but the vulnerable, victim father who gives evidence of the law's omnipotence. Paternal weakness is not the occasion for revolution but for a more thorough submission to the powers that be," figured by the survivor guilt of Caleb's sympathy for Falkland. Godwin's novel thus not only 
anticipates, but fully manifests the ideological implications of the psychoanalytic narrative of how Symbolic power exploits the very fact of its instantiation in the absent Father. Matthew Scott's paper returns us to the source of this power in a primal scene of our critical confrontation with Romanticism's texts, an encounter less missed than productively unsettling. The "unfamiliarity of aesthetic experience," Scott suggests, overturns the critical anticipation of Romantic novelty (itself a Romantic expectation) and thus breaks down critical authority by making us confront this experience as "both embodied and cognitive affect," a "sense of wonder [that] leads us to think ourselves out of a state of uncertain emotion." Scott's questions, like the object of his inquiry (Keats's sonnets on the Elgin marbles) are obvious ones, which is his point because he means to remind us that Romanticism repeatedly returns us to the moment of our encounter with it. At what peril do we forget how Romanticism's "generation of an autonomous aesthetic space," of the creation of Art as a commodity through its attendant criticism, proceeds precisely by provoking "productive confusion and palpable emotional confusion," fundamentals of an aesthetic encounter which place its consequent strategies of containment immediately under erasure?

The above papers, either overtly or intrinsically invoke Romanticism's unceasing Gothic power to arrest and haunt our critical imaginations. In them we can read the still-profound critical and academic influence of Romantic and Gothic Studies in the twenty-first century, and can read them as telling indices of how Romanticism comprises a potently Gothic mode of subverting, re-thinking, and re-writing contemporary history. These essay's critical romance of and with transgression, like that of Romanticism itself, points to what is perhaps one of the period's most lasting legacies: its ability never to trust entirely the myth of its own deviations and defiances, restlessly to seek out within one's romance with transgression a seductive desire for its effectivity, itself a dangerously conservative impulse that threatens to enslave us to the past as lessons already learned. 